\title{
Association of LncRNA MEG3 polymorphisms with efficacy of neoadjuvant chemotherapy in breast cancer
}

Battseren Bayarmaa, Ziping Wu, Jing Peng, Yan Wang, Shuguang Xu, Tingting Yan, Wenjin Yin, Jinsong Lu* (D) and Liheng Zhou* (1)

\begin{abstract}
Background: Breast cancer is the most common malignancy in women, and neoadjuvant chemotherapy has been recommended to the patients with locally advanced breast cancer as the initial treatments. Long non-coding RNA (IncRNA) MEG3, an identified tumor suppressor, has been implicated in the development of various cancers. However, there is no data to evaluate the effect of MEG3 polymorphisms on neoadjuvant treatment in the breast cancer.

Methods: Genotyping was performed using Nanodispenser Spectro CHIP chip spotting and Mass ARRAY Compact System. Univariate and multivariate logistic regression analyses were used to analyze the associations between the MEG3 polymorphisms and the pathological complete response (pCR). The disease-free survival (DFS) was estimated by the Kaplan-Meier method, and multivariate Cox proportional hazards models were used to calculate the hazard ratios (HRs) with a 95\% confidential interval (Cl).

Results: A total of 144 patients with available pretreatment blood species were enrolled in the SHPD002 clinic trial of neoadjuvant chemotherapy for breast cancer. MEG3 rs 10132552 were significantly associated with good response (Adjusted $\mathrm{OR}=2.79,95 \% \mathrm{Cl} 1.096-7.103, p=0.031$ ) in dominant model. Median follow-up time was 20 months. In multiple regression analysis, rs $10132552 \mathrm{TC}+\mathrm{CC}$ (adjusted $\mathrm{HR}=0.127,95 \% \mathrm{Cl} 0.22-0.728, p=0.02$ ) and rs941576 AG + GG (adjusted HR=0.183, 95\% Cl 0.041-0.807, $p=0.025$ ) were significantly associated with good DFS. MEG3 rs7158663 $(\mathrm{OR}=0.377,95 \% \mathrm{Cl} 0.155-0.917, p=0.032)$ were associated with a low risk of hemoglobin decrease in dominant models.

Conclusions: LnCRNA MEG3 polymorphisms were associated with the chemotherapy response and toxicity of paclitaxel and cisplatin. The result indicates that MEG3 polymorphisms can be considered as the predictive and prognostic markers for the breast cancer patients.
\end{abstract}

Trial registration: Retrospectively registered (ClinicalTrials. Gov identifier: NCT02221999); date of registration: Aug 20th, 2014. Keywords: Breast cancer, MEG3 non-coding RNA, Neoadjuvant therapy, Cisplatin, Paclitaxel

\footnotetext{
*Correspondence: lujjss@163.com; kaneshiro_lily@hotmail.com

Department of Breast Surgery, Renji Hospital, School of Medicine, Shanghai

Jiaotong University, 160 Pujian Road, Shanghai 200127, People's Republic of

China
}

(C) The Author(s). 2019 Open Access This article is distributed under the terms of the Creative Commons Attribution 4.0 International License (http://creativecommons.org/licenses/by/4.0/), which permits unrestricted use, distribution, and reproduction in any medium, provided you give appropriate credit to the original author(s) and the source, provide a link to the Creative Commons license, and indicate if changes were made. The Creative Commons Public Domain Dedication waiver (http://creativecommons.org/publicdomain/zero/1.0/) applies to the data made available in this article, unless otherwise stated. 


\section{Background}

Long non-coding RNAs constitute a heterogeneous group of the ncRNAs that are longer than 200 nucleotides. LncRNAs can regulate gene expression at epigenetic, transcriptional, and post-transcriptional levels, and can affect drug response and toxicity in cancer patients [1]. It was reported that some LncRNAs were tumor suppressor in breast cancer, such as growth arrest-specific 5, neuroblastoma associated transcript 1 , and maternally expressed 3 (MEG3) [2]. We also found that MEG3 was downregulated in the ER positive breast cancer in our previous study [3]. MEG3 is chromosomally located at 14q32.3 in humans [4]. In a pooled analysis, a low expression of MEG3 showed to be associated with low overall survival in cancer patients, but not in the breast cancer patients [5]. However, single nucleotide polymorphisms (SNPs) in MEG3 were reported to affect cell phenotypes and cause the risk of developing cancer [6] and the chemotherapy toxicity [7] in other cancers. There have been no analyses published to date of association between MEG3 and chemotherapy response in breast cancer patients.

Neoadjuvant chemotherapy has been recommended to the patients with locally advanced breast cancer as the initial treatments. Many clinical trials, such as NSABP $\mathrm{B} 18$ and B27, have confirmed that patients with neoadjuvant chemotherapy achieved pCR could be a surrogate for their prognosis $[8,9]$. Hormone receptor status and human epidermal growth factor receptor -2 (HER2) expression were long known as predictors for chemotherapy response $[10,11]$. The addition of platinum to a neoadjuvant chemotherapy in some subtype breast cancer could increase the proportion of patients achieving a pCR $[12,13]$. Platinum containing chemotherapy was recommended as a preferred regimen for recurrent or stage IV patients with triple-negative tumors and germline BRCA1/ 2 mutation in 2019 NCCN clinical practice Guidelines [14]. However, rate of pCR still differs between the subset of patients with same biologic phenotype. We need to look for new markers to predict response independent from the established biological markers. The above data prompted us to conduct this prospective-retrospective analysis of the MEG3 lncRNA polymorphisms in available pretreatment blood specimens of patients enrolled in a clinic trial of neoadjuvant chemotherapy. The efficacy of paclitaxel and cisplatin as neoadjuvant setting has been studied in the SHPD001 trial [15], and the SHPD002 trial, which randomized to combine chemotherapy with endocrine therapy or not, will further prospectively estimate the efficacy of the regimen. Our prespecified objective was to determine whether the certain lncRNA polymorphisms could be the biomarkers to predict the benefit or prognosis. Here we hypothesized that these lncRNA polymorphisms would play important role in response to chemotherapy in breast cancer.

\section{Methods}

\section{Study subjects}

Consecutive, breast cancer patients were collected as part of a clinical trials SHPD002 for patients with locally advanced breast cancer (ClinicalTrials. Gov identifier: NCT02221999). One hundred and forty-four patients with information of SNPs were identified for analysis. The blood samples were collected between September 2015 and August 2017. Women aged $\geq 18$ years old with histologically confirmed locally advanced invasive breast cancer were included. For all patients, paclitaxel $80 \mathrm{mg} / \mathrm{m}^{2}$ was given weekly on day 1 for 16 weeks, and cisplatin $25 \mathrm{mg} / \mathrm{m}^{2}$ was given on days 1,8 and 15 every 28 days for 4 cycles. Patients with hormone receptor-positive cancer or premenopausal patients with triple negative breast cancer were randomized to concurrently receive endocrine therapy or not. Endocrine therapy included letrozole for postmenopausal women and gonadotropin releasing hormone agonist for premenopausal women (Additional file 1: Figure S1). HER2 positive patients could have trastuzumab concurrently with the chemotherapy in the neoadjuvant setting. The trastuzumab was given every week at $4 \mathrm{mg} / \mathrm{kg}$ (cycle1), followed by $2 \mathrm{mg} / \mathrm{kg}$. In this explore analysis we used near pCR which was defined as only a few scattered tumor cells remained or that the residual tumor was $<0.5 \mathrm{~cm}$ in size $[15,16]$. Tumor size and node status were assessed by combining physical examination with magnetic resonance imaging and ultrasound. ER, PR, Ki-67 and HER2 were performed on paraffin-embedded tumor samples from biopsy. Ki-67 levels were recorded as a continuous value, and a ki67 value of $>20 \%$ was high expression according to the Saint Gallen consensus [17]. DFS was defined as the time from surgery to local recurrence, original metastasis, second primary cancer or patient mortality. Informed consent was obtained from all individual participants included in the study.

\section{SNP selection and genotyping}

Whole blood was collected before treatment and stored at $-80^{\circ} \mathrm{C}$. DNA extraction was performed using the TIANamp Genomic DNA Kit. A total of 3 potentially fictional SNPs of MEG3 LncRNA were selected in public database (NCBI/TargentScan), whose minor allele frequency $>0.1$; located in the 3'UTR region or 5'UTR region and were reported to be susceptible factors or predictors in other tumors. MEG3 rs10132552, rs941576 and rs7158663 are the most studied lncRNAs involved in tumorigenesis and drug response. Genotyping was performed using Nanodispenser Spectro CHIP chip spotting and Mass ARRAY Compact System (Sequenom, San Diego, CA, USA) by Shanghai Benegene Biotechnology Co., LTD. Detailed primer sequences were provided in the Additional file 1: Table S1. Genotypes were 
determined with Typer software using default settings after auto clustering. Deidentified specimens were used to make sure that all assays were performed blinded to clinical outcome.

\section{Statistical analysis}

Each SNP was explored in different comparison models in this analysis. For MEG3 rs10132552, genotype TT was used as reference; odds ratio (OR) for TC and CC were computed for additive model. Both TC and CC were combined and compared against TT as reference for dominant model. Recessive model (CC vs TC + TT) and co-dominant model (TT $+\mathrm{CC}$ vs TC) were also estimated. The Fisher exact east was used to test deviation form Hardy Weinberg Equilibrium and Chi-square tests were used to test the association of genotype with clinical characteristics. Multivariate logistical regression was conducted to calculate the association of each genotype with the efficacy and toxicities. Some regularly used clinical and biological characteristics were adjusted in the logistic and cox regression. The DFS was estimated by the Kaplan-Meier method, and multivariate Cox proportional hazards models were used to calculate hazard ratios (HRs) and 95\% CIs. All statistical analyses were performed using PASW Statistics 18 software (IBM Co, Armonk, NY, USA). All tests were two-sided and $p<$ 0.05 was considered significant.

\section{Results}

Patients clinical characteristics and genotype distribution Among all the eligible patients, pretreatment blood species were available for 144 . One hundred and twenty-one (84\%) patients had hormonal receptor positive breast cancers. Fifty-two (36.1\%) cancers were Her2 overexpressed. Fifteen $(10.4 \%)$ patients had triple negative breast cancer. The near $\mathrm{pCR}$ rate was $37.5 \%$ for the entire cohort (Table 1). The genotype frequencies of all the SNPs were in Hardy-Weinberg equilibrium. MEG3 rs10132552 was significantly associated with tumor size in its recessive model $(p=0.022)$ and additive model $(p=0.007)$. Patients containing $\mathrm{T}$ allele in rs10132552 were likely to have larger or more invasive tumor (percentage of T3 and T4: TT $55.3 \%$ and TC 52.6\%) compared with the CC genotypes (12.5\%). Patients containing T allele in rs10132552 had higher level of ki67, while the proportions of high ki67 level in TT and TC genotype were 71.6 and $85.2 \%$, which were significantly higher than that of CC genotype (50\%) (Table 2). Polymorphisms in rs941576 and rs7158663 were not associated with clinical or biological characteristics (Additional file 1: Table S2).

\section{LncRNA polymorphisms and response to chemotherapy} Patients with MEG3 rs10132552 were significantly associated with $\mathrm{pCR}$ in dominant model $(\mathrm{TC}+\mathrm{CC}$ vs. TT
Table 1 Baseline clinical characteristics of all patients

\begin{tabular}{|c|c|c|}
\hline Characteristics & Number of Patients (n) & Percentage (\%) \\
\hline \multicolumn{3}{|l|}{ Age (years) } \\
\hline$\geq 50$ & 58 & 40.3 \\
\hline$<50$ & 86 & 59.7 \\
\hline \multicolumn{3}{|l|}{ Tumor stage } \\
\hline $\mathrm{T} 1-2$ & 68 & 47.2 \\
\hline T3-4 & 73 & 50.7 \\
\hline Unknown & 3 & 2.1 \\
\hline \multicolumn{3}{|l|}{ ER status } \\
\hline Postive & 102 & 70.8 \\
\hline Negative & 42 & 29.2 \\
\hline \multicolumn{3}{|l|}{ PR status } \\
\hline Positive & 114 & 79.2 \\
\hline Negative & 30 & 20.8 \\
\hline \multicolumn{3}{|l|}{ HER2 expression } \\
\hline Positive & 52 & 36.1 \\
\hline Negative & 92 & 63.9 \\
\hline \multicolumn{3}{|l|}{ Ki67 status } \\
\hline Low expression & 33 & 22.9 \\
\hline High expression & 103 & 71.5 \\
\hline unkown & 8 & 5.6 \\
\hline \multicolumn{3}{|l|}{ Subtype } \\
\hline Luminal A-like & 12 & 8.3 \\
\hline Luminal B-like & 108 & 75 \\
\hline $\begin{array}{l}\text { HER2 positive } \\
\text { (non lumninal) }\end{array}$ & 9 & 6.3 \\
\hline Triple negative & 15 & 10.4 \\
\hline \multicolumn{3}{|l|}{ Pathological response } \\
\hline $\begin{array}{l}\text { Complete response } \\
\text { (include near } \mathrm{pCR} \text { ) }\end{array}$ & 54 & 37.5 \\
\hline Partial response & 83 & 57.6 \\
\hline Stable disease & 7 & 4.9 \\
\hline Progression disease & 0 & 0 \\
\hline
\end{tabular}

$\mathrm{OR}=2.396,95 \%$ CI $1.202 \sim 4.777 ; p=0.013)$ and in additive model ( $\mathrm{TC}$ vs. TT OR $=2.376,95 \%$ CI $1.164 \sim 4.847$; $p=0.017)$. In another word, patients with $\mathrm{TC}+\mathrm{CC}$ genotype had a significantly higher $\mathrm{pCR}$ rate compared with TT genotype ( $48.5 \%$ vs. $28.2, p=0.012)$ (Table 3 ). The association is particularly seen in the hormone receptor positive patients $(\mathrm{TC}+\mathrm{CC}$ vs. $\mathrm{TT} \mathrm{OR}=2.773$, 95\% CI 1.263 6.087; $p=0.011$ ), but not in the hormone receptor negative patients $(\mathrm{TC}+\mathrm{CC}$ vs. TT $\mathrm{OR}=1.143$, 95\% CI 0.205 6.366; $p=0.879$ ).

The multivariate regression analysis demonstrated that MEG3 rs10132552 was statistically significant associated with good response (Adjusted OR $=2.79,95 \% \mathrm{CI}$ 1.096-7.103, $p=0.031$ ) in dominant model. High ki67 
Table 2 Association between MEG3 rs10132552 and clinic-pathological parameters of breast cancer patients

\begin{tabular}{|c|c|c|c|c|c|c|c|}
\hline & \multicolumn{3}{|c|}{ rs10132552 n(\%) } & \multicolumn{4}{|l|}{$P$ value } \\
\hline & $\overline{\pi T}$ & $\mathrm{TC}$ & CC & Dominant & Recessive & co-dominant & Additive \\
\hline \multicolumn{8}{|l|}{ T stage } \\
\hline $1 \sim 2$ & $34(44.7)$ & $27(47.4)$ & $7(87.5)$ & 0.37 & $0.022^{*}$ & 0.867 & 0.07 \\
\hline $3 \sim 4$ & $42(55.3)$ & $30(52.6)$ & $1(12.5)$ & & & & \\
\hline \multicolumn{8}{|l|}{ Lymph node status } \\
\hline Negative & $8(11)$ & $10(18.2)$ & $2(25)$ & 0.184 & 0.397 & 0.346 & 0.364 \\
\hline Positive & 65(89) & $45(81.8)$ & $6(75)$ & & & & \\
\hline \multicolumn{8}{|l|}{ ER } \\
\hline Negative & $22(28.2)$ & 18(31) & $2(25)$ & 0.783 & 0.79 & 0.686 & 0.905 \\
\hline Positive & $56(71.8)$ & $40(69)$ & $6(75)$ & & & & \\
\hline \multicolumn{8}{|l|}{$P R$} \\
\hline Negative & 15(19.2) & $14(24.1)$ & $1(12.5)$ & 0.607 & 0.55 & 0.423 & 0.656 \\
\hline Positive & 63(80.8) & $44(75.9)$ & $7(87.5)$ & & & & \\
\hline \multicolumn{8}{|l|}{ HER2 } \\
\hline Negative & $54(69.2)$ & $34(58.6)$ & $4(50)$ & 0.147 & 0.4 & 0.28 & 0.312 \\
\hline Positive & $24(30.8)$ & $24(41.4)$ & $4(50)$ & & & & \\
\hline \multicolumn{8}{|l|}{ Ki67 } \\
\hline Low expression & $21(28.4)$ & $8(14.8)$ & $4(50)$ & 0.221 & 0.08 & $0.037^{*}$ & $0.045^{*}$ \\
\hline High expression & 53(71.6) & $46(85.2)$ & $4(50)$ & & & & \\
\hline \multicolumn{8}{|l|}{ Menopausal status } \\
\hline Premenopausal & $35(44.9)$ & $25(43.1)$ & $2(25)$ & 0.632 & 0.289 & 0.992 & 0.557 \\
\hline Postmenopausal & $43(55.1)$ & $33(56.9)$ & $6(75)$ & & & & \\
\hline
\end{tabular}

Abbreviations: $E R$ estrogen receptor, $P R$ progesterone receptor, HER2 human epidermal growth factor receptor -2

${ }^{*} P<0.05$

level (Adjusted OR $=1.059, p<0.001$ ), HER2 overexpression (Adjusted $\mathrm{OR}=11.718, p<0.001$ ) were also significantly associated with good efficacy. However, patients with old age (Adjusted $\mathrm{OR}=0.951 ., p=0.035$ ) and positive hormonal receptors (Adjusted $\mathrm{OR}=0.241$, $p=0.022$ ) were less likely to have good response (Table 4). Meanwhile, MEG3 rs941576 and rs7158663 polymorphisms were not associated with the response to chemotherapy in neither univariate nor multivariate analyses.

\section{LncRNAs polymorphisms and prognosis}

The median follow-up was $20(2-40)$ months. The result showed that DFS in patients with MEG3 rs7158663 AG + AA genotype was better than that with GG genotype, and DFS was 94.4 and $85.3 \%(p=0.017)$, respectively. In patients with rs941576 AG + GG genotype, the DFS was 98\%, which was better than $89.7 \%(P=0.028)$ in patients with AA genotype. The DFS of patients with rs10132552 CC + CT was $94 \%$, which was significantly better than that with TT genotype (90.7\%) $(P=0.018)$ (Fig. 1).

Table 3 Association between IncRNA MEG3 polymorphisms and pCR rate in different comparison models

\begin{tabular}{|c|c|c|c|c|c|c|c|c|c|c|c|}
\hline \multirow[t]{2}{*}{$\overline{S N P}$} & \multirow{2}{*}{$\begin{array}{l}\text { Dominant model } \\
\text { Genotypes }\end{array}$} & \multirow{2}{*}{$\begin{array}{l}\mathrm{pCR} \\
\mathrm{n}(\%)\end{array}$} & \multirow{2}{*}{$\begin{array}{l}\text { Non-pCR } \\
\mathrm{n}(\%)\end{array}$} & \multirow[t]{2}{*}{$P$} & \multicolumn{2}{|l|}{ Dominant model } & \multicolumn{2}{|l|}{ Recessive model } & \multicolumn{3}{|c|}{ Additive model } \\
\hline & & & & & $\overline{\mathrm{OR}(95 \% \mathrm{Cl})}$ & $P$ & $\overline{\mathrm{OR}(95 \% \mathrm{Cl})}$ & $P$ & $\overline{\mathrm{OR}(9}$ & $95 \% \mathrm{Cl})$ & $P$ \\
\hline \multirow[t]{2}{*}{ rs10132552 } & $\pi$ & $22(28.2)$ & $56(71.8)$ & $0.012^{*}$ & $2.396(1.202 \sim 4.777)$ & $0.013^{*}$ & $1.72(0.412 \sim 7.181)$ & 0.457 & TC & $2.376(1.164 \sim 4.847)$ & $0.017^{*}$ \\
\hline & $\mathrm{TC}+\mathrm{CC}$ & $32(48.5)$ & $34(51.5)$ & & & & & & $\mathrm{CC}$ & $2.545(0.585 \sim 11.082)$ & 0.213 \\
\hline \multirow[t]{2}{*}{ rs941576 } & $\mathrm{AA}$ & $22(31.9)$ & $47(68.1)$ & 0.182 & $1.59(0.803 \sim 3.146)$ & 0.183 & $2.194(0.563 \sim 8.554)$ & 0.258 & $A G$ & $1.479(0.731 \sim 2.994)$ & 0.277 \\
\hline & $A G+G G$ & $32(42.7)$ & $43(57.3)$ & & & & & & GG & 2.67(0.653 10.926) & 0.172 \\
\hline \multirow[t]{2}{*}{ rs7158663 } & GG & $28(34.1)$ & $54(65.9)$ & 0.339 & $1.393(0.705 \sim 2.75)$ & 0.34 & $2.959(0.678 \sim 12.916)$ & 0.149 & $A G$ & $1.227(0.602 \sim 2.503)$ & 0.573 \\
\hline & $A G+A A$ & 26(41.9) & $36(58.1)$ & & & & & & AA & $3.214(0.716 \sim 14.44)$ & 0.128 \\
\hline
\end{tabular}


Table 4 Multivariate regression analysis for predicting factors of PCR rate

\begin{tabular}{llll}
\hline Variables & & $\begin{array}{l}\text { Adjusted OR } \\
(95 \% \mathrm{Cl})\end{array}$ & $P$ \\
\hline MEG3 rs10132552 & CC + TC vs. TT & $2.79(1.096-7.103)$ & $0.031^{*}$ \\
Tumor size & Continuous Variable & $1.002(0.96-1.045)$ & 0.943 \\
Age & Continuous Variable & $0.951(0.907-0.996)$ & $0.035^{*}$ \\
Ki67 & Continuous Variable & $1.059(1.033-1.086)$ & $<0.001^{*}$ \\
Her2 expression & Positive vs. negative & $11.718(3.974-34.554)$ & $<0.001^{*}$ \\
Hormone receptor & Positive vs. negative & $0.241(0.071-0.811)$ & $0.022^{*}$
\end{tabular}

Abbreviations: OR odds ratio, HER2 human epidermal growth factor receptor -2

${ }^{*} P<0.05$

Linkage disequilibrium analysis indicated the SNPs rs10132552 and $\mathrm{rs} 941576\left(\mathrm{r}^{2}=0.842, \mathrm{D}^{\prime}=0.987\right)$ were strongly linked. We further analyzed them as rs10132552 TT+ rs941576 AA haplotype which was significantly associated with poor DFS (HR $=0.257$, 95\% CI 0.0690.951, $p=0.042$ ) when it's compared with other haplotypes. When considered with the rs7158663, patients with rs10132552TT+ rs941576AA + rs7158663GG were also significantly associated with poor DFS $(\mathrm{HR}=0.175$, 95\% CI $0.047-0.648, p=0.009)$. Multivariate analysis demonstrated the similar results (Table 5). In multiple stepwise selection Cox models, rs10132552 TC + CC (adjusted HR $=0.127,95 \%$ CI $0.22-0.728, p=0.02$ ) and rs941576 AG + GG (adjusted $\mathrm{HR}=0.183, \quad 95 \%$ CI $0.041-0.807, p=0.025)$ patients were also significantly associated with good DFS when adjusted by ki67, tumor size, lymph nodes, hormone receptor, HER2 expression and age.

\section{Discussion}

In this study, we detected the SNPs of long chain noncoding RNA MEG3 and analyzed the relationships between the polymorphisms and clinicopathological features, neoadjuvant chemotherapy sensitivity, prognosis and the toxicities of breast cancer patients. As far as we know, this is the first time to report the relationship between MEG3 lncRNA polymorphisms, efficacy and prognosis in locally advanced breast cancer patients who received neoadjuvant chemotherapy.

In our exploratory analysis, patients containing $\mathrm{T}$ allele in rs10132552 had higher level of ki67. MEG3 as a kind of tumor suppressor lncRNA, its mechanism of action has been widely studied in the occurrence and metastasis of tumor. Zhang's study showed that MEG3 could reduce gliomas growth, tumor volume and the expression of ki67 [18]. Our result indicated that the MEG3 polymorphism was also associated with cell growth in breast cancers.

We observed that patients with MEG3 rs10132552 $\mathrm{TC}+\mathrm{CC}$ genotype tended to achieve higher $\mathrm{pCR}$ rate

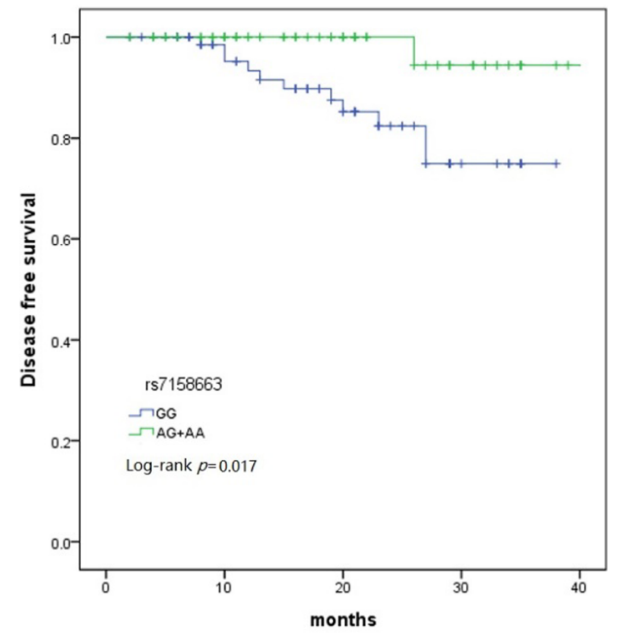

b
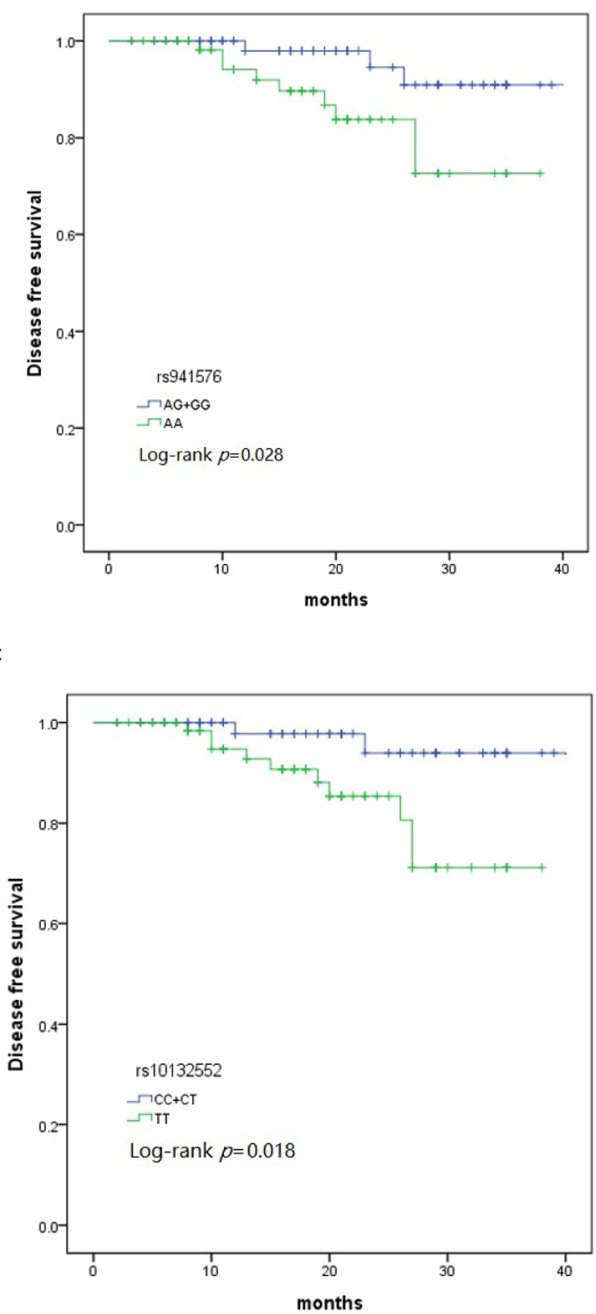

Fig. 1 Kaplan-Meier Analysis of Disease-Free Survival. Disease-free survival by rs7158663 dominant model (a), rs941576 dominant model (b) and rs10132552 dominant model (c) 
Table 5 DFS according to MEG3 Polymorphisms

\begin{tabular}{|c|c|c|c|c|c|c|}
\hline Gene & SNP & Genotype & DFS HR $(95 \% \mathrm{Cl})$ & $P$ & DFS Adjusted HR (95\% Cl) & $P$ \\
\hline \multirow[t]{10}{*}{ MEG3 } & rs10132552 & $\pi$ & 1 & & 1 & \\
\hline & & $\mathrm{TC}+\mathrm{CC}$ & $0.193(0.042-0.884)$ & $0.034^{*}$ & $0.127(0.22-0.728)$ & $0.02^{*}$ \\
\hline & rs941576 & $\mathrm{AA}$ & 1 & & 1 & \\
\hline & & $\mathrm{AG}+\mathrm{GG}$ & $0.257(0.069-0.951)$ & $0.042^{*}$ & $0.183(0.041-0.807)$ & $0.025^{*}$ \\
\hline & rs7158663 & GG & 1 & & 1 & \\
\hline & & $A G+A A$ & $0.124(0.016-0.964)$ & $0.046^{*}$ & 0.155(0.019-1.236) & 0.078 \\
\hline & rs10132552+ rs941576 & $\Pi+A A$ & 1 & & 1 & \\
\hline & & others & $0.257(0.069-0.951)$ & $0.042^{*}$ & $0.183(0.041-0.807)$ & $0.025^{*}$ \\
\hline & rs10132552+ rs941576 + rs 7158663 & $\pi+A A+G G$ & 1 & & 1 & \\
\hline & & Others & $0.175(0.047-0.648)$ & $0.009^{*}$ & $0.116(0.025-0.552)$ & $0.007^{*}$ \\
\hline
\end{tabular}

Adjusted by ki67, tumor size, lymph nodes, hormone receptor, HER2 expression and age

Abbreviations: $H R$ hazard ratio; DFS Disease-free survival, $H E R 2$ human epidermal growth factor receptor -2

${ }^{*} P<0.05$

than those with major allele homozygous. In Silico's analysis, MEG3 rs10132552 was reported to change the structure of the transcript when the $\mathrm{T}$ allele was substituted by the $\mathrm{C}$ allele, and change the minimum free energy from $-150.6 \mathrm{kcal} / \mathrm{mol}$ to $-153.3 \mathrm{kcal} / \mathrm{mol}$, which might alter the local RNA folding structure [19]. The change of structure might alter its potential function via certain regulating signals, resulting in different response to the therapy. In MEG3 overexpressing bladder cancer, cisplatin could significantly induce cell apoptosis, down-regulate bcl2 expression and up-regulate cleaved-caspase-3 and bax expression [20]. Wang's study showed that nasopharyngeal carcinoma patients with MEG3 rs10132552 CT genotype had a better response to treatment $(\mathrm{OR}=0.261, p=0.015)$ [19]. In lung cancer, MEG3 could enhance the chemosensitivity through regulation the WNT/beta catenin signaling pathway and miR$21-5 \mathrm{p} / \mathrm{SOX} 7$ axis $[21,22]$. The regulative effect of MEG3 on miR-214 expression was associated with cisplatin resistance in ovarian cancer cells [23]. In breast caner cells, MEG3 inhibits cell growth and induces apoptosis, partially via the activation of the ER stress, nuclear factor $\kappa B$ (NF$\kappa B)$ and p53 pathways, and that NF- $\kappa B$ signaling is required for MEG3-induced p53 activation in breast cancer cells [24]. These pathways might be the potential function for MEG3 to affect the response to chemotherapy in breast cancer patients.

We also observed that patients with MEG3 rs10132552 TT had worse DFS both in univariate and multivariate analysis. Perhaps this might be owing to the lower $\mathrm{PCR}$ rate of the patients with this genotype. MEG3 expression was reported to be an independent prognostic factor in breast cancer [25]. In other tumors, such as gastric cancer, overexpression of MEG3 could decrease the proliferation and metastasis via p53 signaling pathway [26]. MEG3 was also reported to suppress pancreatic neuroendocrine tumor growth by down regulating miR-183/BRI3 axis [27]. MEG3 could regulate the TGF- $\beta$ pathway through formation of RNA-DNA triplex structures and finally target chromatin [28]. As a result, the patients with rs10132552 TT genotype had a substantially worse DFS than other cohorts. In addition, our data showed rs 941576 which located in the intron of MEG3 was associated with DFS, too. There are few reports of this loci in tumors, and it was reported to be associated with fetal growth [29] and type I diabetes [30,31]. Its effects on the survival of breast cancer patients might be associated with rs10132552.

The present study had some limitations. Our survival analyses were focused on DFS, the data of OS are not available now. Whether the MEG3 SNPs will be associated with the overall survival needs further study. The precise mechanisms of SNPs and efficacy remain unknown, and basic research is also necessary to study.

\section{Conclusions}

In conclusion, MEG3 rs10132552 was associated with the cisplatin-containing chemotherapy response in breast cancer patients, and MEG3 rs10132552 and rs941576 were associated with disease free survival. All these SNPs might be considered as potential predictive markers for cisplatin-based neoadjuvant chemotherapy for breast cancer patients.

\section{Additional file}

Additional file 1: Table S1. Detailed primer sequences of SNPs in MEG3 LncRNA. Table S2. Correlation between MEG3 rs941576 and rs7158663 and clinic-pathological parameters. Figure S1. Trial design (DOC $150 \mathrm{~kb})$

\section{Abbreviations}

Cl: confidential interval; DFS: disease-free survival; ER: estrogen receptor: HER2: human epidermal growth factor receptor - 2; HR: hazard ratio; IncRNA: Long non-coding RNA; MEG3: maternally expressed gene3; NF$\mathrm{KB}$ : nuclear factor $\mathrm{KB}$; OR: odds ratio; $\mathrm{pCR}$ : pathological complete remission; PR: progesterone receptor; SNPs: single nucleotide polymorphisms 


\section{Acknowledgments}

We thank all the staff at Department of Breast Surgery, Renji Hospital, School of Medicine, Shanghai Jiaotong University.

\section{Authors' contributions}

LHZ acquired data, analyzed data and wrote the manuscript. JSL designed the study, controlled the quality of data and algorithms, and edited the manuscript. BB carried out the experimental operation. ZPW, JP and YW edited the manuscript. SGX and TTY provided patient samples. WJY review the manuscript. All authors read and approved the final manuscript.

\section{Funding}

This work was supported by Multidisciplinary Cross Research Foundation of Shanghai Jiaotong University [grant number YG2017QN49; ZH2018QNA42]; Clinical Research Plan of SHDC [grant number 16CR3065B]; the Nurturing Fund of Renji Hospital [grant number pyzy16-018]; Science and Technology Commission of Shanghai Municipality [grant number 15JC1402700]; Shanghai Municipal Commission of Health and Family Planning [grant numbers 201640006] and National Natural Science Foundation of China [grant number 81172505]. The funding bodies had no role in the study design, data collection, analysis and interpretation, or in writing the manuscript.

\section{Availability of data and materials}

The datasets used and/or analyzed during the current study are available from the corresponding author on reasonable request.

\section{Ethics approval and consent to participate}

The study was approved by independent ethics committees of RenJi Hospital, Shanghai Jiao Tong University. The committee's reference numbers are [2014]14 $\mathrm{k}$ and [2017]088. Written informed consent was obtained from all patients.

\section{Consent for publication}

Not applicable

\section{Competing interests}

The authors declare that they have no competing interests.

Received: 25 November 2018 Accepted: 5 August 2019 Published online: 05 September 2019

\section{References}

1. Huarte M. The emerging role of IncRNAs in cancer. Nat Med. 2015;21(11): 1253-61.

2. Youness RA, Gad MZ. Long non-coding RNAs: functional regulatory players in breast cancer. Noncoding RNA Res. 2019;4(1):36-44.

3. Peng J, Zhang L, Yuan C, Zhou L, Xu S, Lin Y, Zhang J, Yin W, Lu J. Expression profile analysis of long noncoding RNA in ER-positive subtype breast cancer using microarray technique and bioinformatics. Cancer Manag Res. 2017;9:891-901.

4. Zhou Y, Zhang X, Klibanski A. MEG3 noncoding RNA: a tumor suppressor. J Mol Endocrinol. 2012;48(3):R45-53.

5. Binabaj MM, Bahrami A, Bahreyni A, Shafiee M, Rahmani F, Khazaei M, Soleimanpour S, Ghorbani E, Fiuji H, Ferns GA, et al. The prognostic value of long noncoding RNA MEG3 expression in the survival of patients with cancer: a meta-analysis. J Cell Biochem. 2018;119(11):9583-90.

6. Cao X, Zhuang S, Hu Y, Xi L, Deng L, Sheng H, Shen W. Associations between polymorphisms of long non-coding RNA MEG3 and risk of colorectal cancer in Chinese. Oncotarget. 2016;7(14):19054-9.

7. Gong WJ, Peng JB, Yin JY, Li XP, Zheng W, Xiao L, Tan LM, Xiao D, Chen YX, $\mathrm{Li} X$, et al. Association between well-characterized lung cancer IncRNA polymorphisms and platinum-based chemotherapy toxicity in Chinese patients with lung cancer. Acta Pharmacol Sin. 2017;38(4):581-90.

8. Fisher B, Bryant J, Wolmark N, Mamounas E, Brown A, Fisher ER, Wickerham DL, Begovic M, DeCillis A, Robidoux A, et al. Effect of preoperative chemotherapy on the outcome of women with operable breast cancer. J Clin Oncol. 1998; 16(8):2672-85.

9. Bear HD, Anderson S, Brown A, Smith R, Mamounas EP, Fisher B, Margolese $\mathrm{R}$, Theoret $\mathrm{H}$, Soran $\mathrm{A}$, Wickerham $\mathrm{DL}$, et al. The effect on tumor response of adding sequential preoperative docetaxel to preoperative doxorubicin and cyclophosphamide: preliminary results from National Surgical Adjuvant Breast and bowel project protocol B-27. J Clin Oncol. 2003;21(22):4165-74.

10. Rouzier R, Perou CM, Symmans WF, Ibrahim N, Cristofanilli M, Anderson K, Hess KR, Stec J, Ayers M, Wagner P, et al. Breast cancer molecular subtypes respond differently to preoperative chemotherapy. Clin Cancer Res. 2005; 11(16):5678-85.

11. Colleoni M, Viale G, Zahrieh D, Bottiglieri L, Gelber RD, Veronesi P, Balduzzi A, Torrisi R, Luini A, Intra M, et al. Expression of ER, PgR, HER1, HER2, and response: a study of preoperative chemotherapy. Ann Oncol. 2008;19(3): 465-72.

12. von Minckwitz G, Schneeweiss A, Loibl S, Salat C, Denkert C, Rezai M, Blohmer $J U$, Jackisch C, Paepke S, Gerber B, et al. Neoadjuvant carboplatin in patients with triple-negative and HER2-positive early breast cancer (GeparSixto; GBG 66): a randomised phase 2 trial. Lancet Oncol. 2014;15(7):747-56.

13. Golshan M, Cirrincione CT, Sikov WM, Berry DA, Jasinski S, Weisberg TF, Somlo G, Hudis C, Winer E, Ollila DW, et al. Impact of neoadjuvant chemotherapy in stage II-III triple negative breast cancer on eligibility for breast-conserving surgery and breast conservation rates: surgical results from CALGB 40603 (Alliance). Ann Surg. 2015;262(3):434-9 discussion 438-439.

14. National Comprehensive Cancer Network Guidelines - Breast Cancer. Version 1.2019. https://www.NCCN.org. Accessed 14 Mar 2019.

15. Zhou L, Xu S, Yin W, Lin Y, Du Y, Jiang Y, Wang Y, Zhang J, Wu Z, Lu J. Weekly paclitaxel and cisplatin as neoadjuvant chemotherapy with locally advanced breast cancer: a prospective, single arm, phase II study. Oncotarget. 2017;8(45):79305-14.

16. Rodenhuis S, Mandjes IA, Wesseling J, van de Vijver MJ, Peeters MJ, Sonke GS, Linn SC. A simple system for grading the response of breast cancer to neoadjuvant chemotherapy. Ann Oncol. 2010;21(3):481-7.

17. Coates AS, Winer EP, Goldhirsch A, Gelber RD, Gnant M, Piccart-Gebhart M, Thurlimann B, Senn HJ, Panel M. Tailoring therapies--improving the management of early breast cancer: St Gallen international expert consensus on the primary therapy of early breast Cancer 2015. Ann Oncol. 2015;26(8):1533-46.

18. Zhang $L$, Liang $X$, Li Y. Long non-coding RNA MEG3 inhibits cell growth of gliomas by targeting miR-93 and inactivating PI3K/AKT pathway. Oncol Rep. 2017;38(4):2408-16.

19. Wang Y, Guo Z, Zhao Y, Jin Y, An L, Wu B, Liu Z, Chen X, Chen X, Zhou H, et al. Genetic polymorphisms of IncRNA-p53 regulatory network genes are associated with concurrent chemoradiotherapy toxicities and efficacy in nasopharyngeal carcinoma patients. Sci Rep. 2017;7(1):8320.

20. Feng SQ, Zhang XY, Fan HT, Sun QJ, Zhang M. Up-regulation of LncRNA MEG3 inhibits cell migration and invasion and enhances cisplatin chemosensitivity of bladder cancer cells. Neoplasma. 2018;65(6):925-32.

21. Xia $Y$, He Z, Liu B, Wang P, Chen Y. Downregulation of Meg3 enhances cisplatin resistance of lung cancer cells through activation of the WNT/betacatenin signaling pathway. Mol Med Rep. 2015;12(3):4530-7.

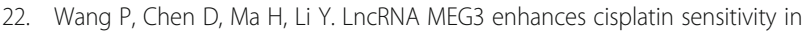
non-small cell lung cancer by regulating miR-21-5p/SOX7 axis. Onco Targets Ther. 2017;10:5137-49.

23. Zhang J, Liu J, Xu X, Li L. Curcumin suppresses cisplatin resistance development partly via modulating extracellular vesicle-mediated transfer of MEG3 and miR-214 in ovarian cancer. Cancer Chemother Pharmacol. 2017; 79(3):479-87.

24. Zhang $Y$, Wu J, Jing H, Huang G, Sun Z, Xu S. Long noncoding RNA MEG3 inhibits breast cancer growth via upregulating endoplasmic reticulum stress and activating NF-kappaB and p53. J Cell Biochem. 2019;120(4):6789-97.

25. Zhang JJ, Guo SH, Jia BQ. Down-regulation of long non-coding RNA MEG3 serves as an unfavorable risk factor for survival of patients with breast cancer. Eur Rev Med Pharmacol Sci. 2016;20(24):5143-7.

26. Wei GH, Wang X. IncRNA MEG3 inhibit proliferation and metastasis of gastric cancer via p53 signaling pathway. Eur Rev Med Pharmacol Sci. 2017; 21(17):3850-6.

27. Zhang YY, Feng HM. MEG3 suppresses human pancreatic neuroendocrine tumor cells growth and metastasis by Down-regulation of Mir-183. Cell Physiol Biochem. 2017:44(1):345-56.

28. Mondal T, Subhash S, Vaid R, Enroth S, Uday S, Reinius B, Mitra S, Mohammed A, James AR, Hoberg E, et al. MEG3 long noncoding RNA regulates the TGF-beta pathway genes through formation of RNA-DNA triplex structures. Nat Commun. 2015;6:7743.

29. Moore GE, Ishida M, Demetriou C, Al-Olabi L, Leon $\amalg$, Thomas AC, AbuAmero S, Frost JM, Stafford JL, Chaoqun $Y$, et al. The role and interaction of 
imprinted genes in human fetal growth. Philos Trans R Soc Lond Ser B Biol Sci. 2015;370(1663):20140074.

30. Wallace C, Smyth DJ, Maisuria-Armer M, Walker NM, Todd JA, Clayton DG. The imprinted DLK1-MEG3 gene region on chromosome 14q32.2 alters susceptibility to type 1 diabetes. Nat Genet. 2010;42(1):68-71.

31. Kiani AK, Jahangir S, John P, Bhatti A, Zia A, Wang X, Demirci FY, Kamboh MI. Genetic link of type 1 diabetes susceptibility loci with rheumatoid arthritis in Pakistani patients. Immunogenetics. 2015;67(5-6):277-82.

\section{Publisher's Note}

Springer Nature remains neutral with regard to jurisdictional claims in published maps and institutional affiliations.

Ready to submit your research? Choose BMC and benefit from:

- fast, convenient online submission

- thorough peer review by experienced researchers in your field

- rapid publication on acceptance

- support for research data, including large and complex data types

- gold Open Access which fosters wider collaboration and increased citations

- maximum visibility for your research: over $100 \mathrm{M}$ website views per year

At BMC, research is always in progress.

Learn more biomedcentral.com/submissions 